\title{
Effect of High Dose Amlodipine to Nrf2 Protein on SH-SY5Y Cell Culture That Induced with Glucose $50 \mathrm{mM}$
}

\author{
Shahdevi N. K., Muhyiddin A. A. A., Machlusil H.
}

\begin{abstract}
Diabetes Mellitus is a chronic metabolic disease characteristic by the presence of chronic hyperglycemia that glucose levels $>200 \mathrm{mg} / \mathrm{dL}$. Protein Nrf2 is a transcription factor protein for antioxidant genes that serves to capture reactive oxygen species (ROS) which increases in the condition of diabetes mellitus. To investigate the effect of the administration of amlodipine on protein expression of $\mathrm{Nrf} 2$ in $\mathrm{SH}-\mathrm{SY} 5 \mathrm{Y}$ neuron cell culture that induced by glucose $50 \mathrm{mM}$. This research were used the method of pure experimental analysis in the laboratory used cell cultures of the SH-SY5Y neurons. Cell culture SH-SY5Y neurons were induced with glucose $50 \mathrm{mM}$ for 6 days. Then administered amlodipine with a dose of $5 \mu M$ for 30 minutes. Then expression of Nrf2 proteins observed with immunofluorescence. Independent t-test and Pearson statistical analyses were conducted to determine the influence and relationship of a 5 $\mu M$ amlodipine on protein expression $\mathrm{Nrf} 2$. In the group of administering amlodipine $5 \mu M$ and without amlodipine on the cell culture of the SH-SY5Y neurons that induced of chronic hyperglycemia (glucose $50 \mathrm{mM}$ ) result of independent t-test obtained that there is no meaningful difference $(P=0.464)$. Pearson correlation test result in get a correlation coefficient value of 0.223. There is an increased expression of the protein Nrf2 after the administration of the dose of amlodipine $5 \mu M$ although not significant.
\end{abstract}

Keywords : Nrf2, amlodipine, SH-SY5Y, neuron, glucose.

\section{INTRODUCTION}

$\mathrm{D}$ iabetes mellitus is a chronic metabolic disease characterized by chronic hyperglycemia followed by an imbalance in the metabolism of proteins, fats, and carbohydrates. One of the etiologies of diabetes mellitus can be caused by a lack of secretion from the hormone insulin or an ineffective insulin response or both [1]. Diabetes mellitus as one of the non-communicable diseases (PTM) has a high prevalence in Indonesia. The prevalence of diabetes mellitus in Indonesia based on doctor's diagnosis and symptoms experienced by patients reaches $6.9 \%$ or around 12 million people through respodent Indonesian society over 15 years [2]. Uncontrolled diabetes mellitus causes 2.2 million deaths

Revised Manuscript Received on January 2, 2020.

* Correspondence Author

Shahdevi N. K.*, Neurology Department, Medical Faculty of Brawijaya University, Malang, Indonesia. Email: shahdevinandar@yahoo.com

Muhyiddin A. A. A., Medical Faculty of Brawijaya University, Malang, Indonesia. Email: afrizal.alif.am@gmail.com

Machlusil H., Neurology Department, Medical Faculty of Brawijaya University, Malang, Indonesia. Email: machlusilhusna@yahoo.com due to cardiovascular risk factors and other diseases. The prevalence of death from diabetes mellitus by $43 \%$ of 3.7 million deaths occurs at the age of less than 70 years [3]. Diabetes mellitus causes both macrovascular and microvascular complications. Microvascular complications of chronic hyperglycemia that can occur are: diabetic retinopathy in the eye, diabetic nephropathy in the kidneys, and diabetic neuropathy in the nerve. Complications that can occur macrovascular namely: coronary heart disease, stroke, peripheral arterial disease [4]. Complications that often occur namely diabetic neuropathy can be caused by several factors including: hyperglycemia followed by metabolic syndrome, sorbitol accumulation, oxidative stress, and activation of 12/15-lipoxygenase and several other factors that indicate the relationship between diabetes and peripheral neuropathy. The impact of diabetic neuropathy in terms of quality of life is the problem of emotional disturbances, physical disorders, mental health disorders, social functioning disorders, physical function disorders, and pain disorders in the body [5].

One of the causes of diabetic neuropathy is the abnormal homeostasis of calcium ions $\left(\mathrm{Ca}^{2+}\right)$ due to chronic and untreated hyperglycemic processes. The mechanism of neuropathy in this condition is mitochondrial dysfunction through the disruption of $\mathrm{Ca}^{2+}$ ion homeostasis and the disruption of the $\mathrm{Ca}^{2+}$ ion buffer system in the mitochondria by limiting the amount of ATP dependent transport. This results in a steady increase in intracellular $\mathrm{Ca}^{2+}$ ion concentration, a regular increase in $\mathrm{Ca}^{2+}$ flow, and a decrease in the amplitude of the $\mathrm{Ca}^{2+}$ ion depolarization induction signal [6]. In acute hyperglycemic conditions there will be an increase in the expression of the protein Nrf2 to reduce the conditions of oxidative stress in the cell. However, in chronic hyperglycemic conditions there is a decrease in Nrf2 protein expression due to the activation of the nuclear factor kappa $\mathrm{B}$ (NF-kB), protein kinase $\mathrm{C}(\mathrm{PKC})$, mitogen-activated protein kinase (MAPK), and glycogen synthase kinase-3 (GSK3) activity [7]. In previous studies, amlodipine was administered at doses of 4 and $10 \mathrm{mg} / \mathrm{kg}$ in mice induced by increased free radicals (ROS) through the acute mountain sickness model, which was able to increase the expression of Nrf2 protein in microvascular cell culture of endothelial brain [8]. In this case the researcher wanted to know the effect of giving amlodipine on the expression of Nrf2 protein in $50 \mathrm{mM}$ glucose-induced SH-SY5Y cell culture. So 
that it can be used as a scientific foundation for the role of amlodipine on the activation of the Nrf2 protein in chronic hyperglycemic conditions.

Aim for this research is knowing the effect of giving $5 \mu \mathrm{M}$ amlodipine on $\mathrm{Nrf} 2$ protein expression in SH-SY5Y neuron-induced glucose cell culture $50 \mathrm{mM}$.

\section{MATERIALS AND METHODS}

Early studies using the method of pure experimental analysis in vitro in the SH-SY5Y cell culture with the independent sample t-test approach and Pearson correlation test. The process of culture and measurement of all related parameters and morphology of neurons was carried out at the Central Laboratory of Life Sciences (LSIH) Universitas Brawijaya Malang. In this study the SH-SY5Y cell line neurons were cultured. Cell culture was then induced by glucose with a concentration of $50 \mathrm{mM}$ for 6 days. Then after 6 days amlodipine was given at a dose of $5 \mu \mathrm{M}$ for 30 minutes. Then the observations of the Nrf2 parameters were examined using antibodies by immunoflorescence. All data were processed using dSPSS for Windows version 24 .

\section{RESULTS AND DISCUSSION}

In the $5 \mu \mathrm{M}$ amlodipine group and without amlodipine in the SH-SY5Y cell culture induced by chronic hyperglycemia (glucose $50 \mathrm{mM}$ ), the average independent t-test results obtained showed that there were no significant differences ( $\mathrm{p}$ $=0.464)$. This means that in the SH-SY5Y cell culture induced by $50 \mathrm{mM}$ glucose induction for 6 days amlodipine given a dose of $5 \mu \mathrm{M}$ will show expression of Nrf2 that is no different from those without amlodipine.
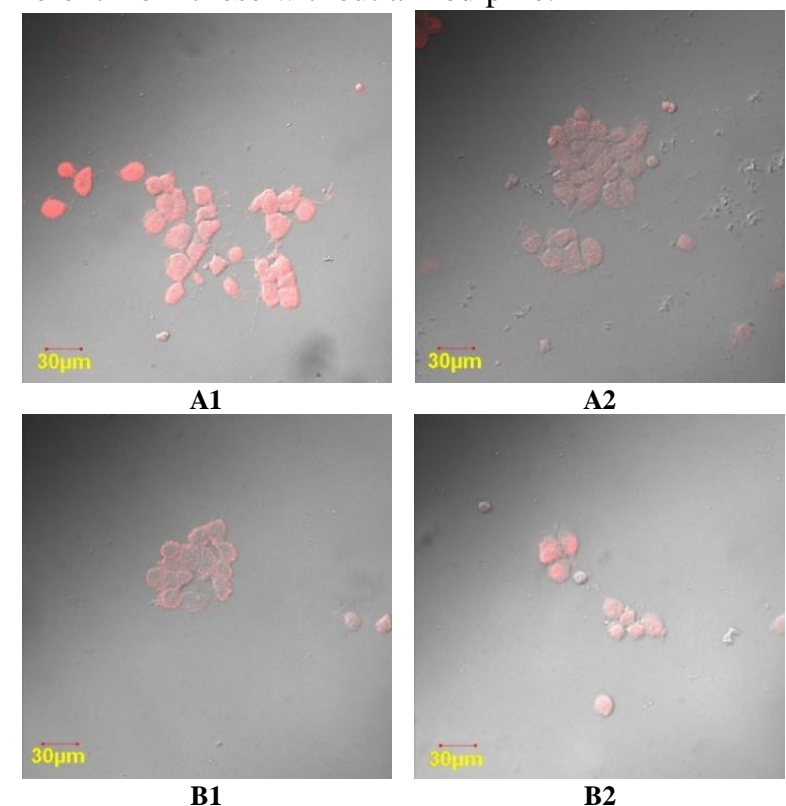

Fig. 1. Nrf2 expression in neuron culture by treating hyperglycemia $(50 \mathrm{mM})$.

Figures 1, A1 and A2 without amlodipine administration, figures B1 and B2 are treated with $5 \mu \mathrm{M}$ amlodipine. (culture 6th day, Nrf2 red rhodamine, DIC, superimpose, 400x enlargement).

Table I. Comparison results of $50 \mathrm{mM}$ hyperglycemia neuronal Nrf2 expression.

\begin{tabular}{|c|c|c|c|}
\hline Variabel & $\begin{array}{c}\text { Without } \\
\text { Amlodipine } \\
\text { Mean } \pm \mathrm{SD}\end{array}$ & $\begin{array}{c}\text { Amlodipine } \\
5 \mu \mathrm{M} \\
\text { Mean } \pm \mathrm{SD}\end{array}$ & p-value \\
\hline $\begin{array}{c}\text { Nrf2 } \\
\text { Expression }\end{array}$ & $8.59 \pm 1.08$ & $9.24 \pm 1.94$ & $0.46=4>\propto$ \\
\hline
\end{tabular}

Note: If $\mathrm{p}$-value $<0.05$ means there is a significant difference and if $\mathrm{p}$-value $>$ 0.05 means there is no significant difference.

Pearson correlation test results obtained correlation coefficient of 0.223 . This shows that there is a weak relationship between the group giving amlodipine dose of 5 $\mu \mathrm{M}$ with the group without amlodipine given in SH-SY5Y cell culture after glucose induction for 6 days. In this case it can be said that there is no influence between the group given amlodipine dose $5 \mu \mathrm{M}$ with the group without amlodipine and there is no relationship between the group given amlodipine $5 \mu \mathrm{M}$ dose with the group without amlodipine.

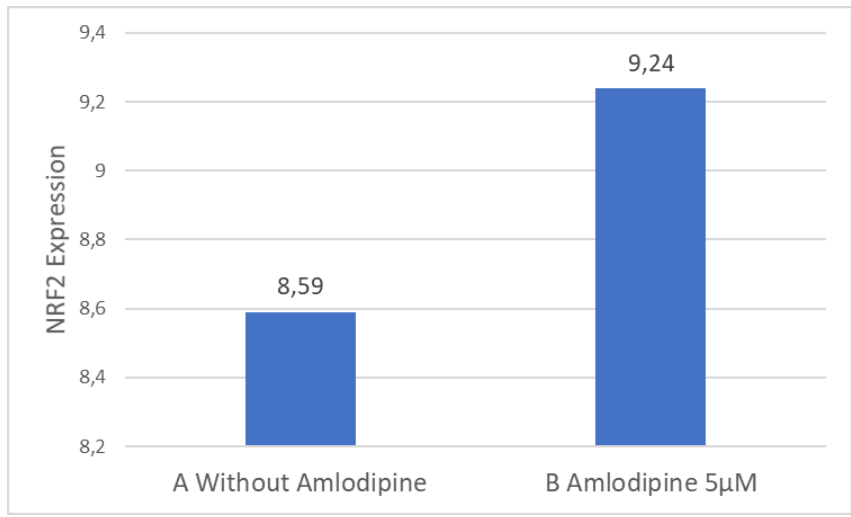

Fig 2. Comparison of average Nrf2 protein expression.

Figure 2 show comparison of average of Nrf2 protein expression of $5 \mu \mathrm{M}$ amlodipine and without amlodipine in 50 $\mathrm{mM}$ glucose induction SH-SY5Y cell culture.

\section{A. Effect of Amlodipine on Nrf2 Protein}

Amlodipine administration at a dose of $5 \mu \mathrm{M}$ and without amlodipine in the SH-SY5Y neuron culture model with chronic hyperglycemia (50 $\mathrm{mM}$ glucose induction) can increase the expression of Nrf2 protein but not statistically significant. This is consistent with the theory that $50 \mathrm{mM}$ glucose induction in cortical neuron cell culture will cause increased production of ROS levels [9]. At the time of neuron cells exposed to chronic hyperglycemia (6 days) there is a process of cell defense mechanisms against ROS. One of them is the activation of the Nrf2-ARE (antioxidant responsive element) system in the nucleus of neuron cells and the end result is the production of antioxidant enzymes for example superoxide dismutase (SOD) [10]. Activation of the Nrf2-ARE-SOD system will cause capture of free radicals (ROS) so that it will reduce the process of damage from SH-SY5Y cells. In this study an increase in expression of the Nrf2 protein after administration of amlodipine was not significant. An increase in the expression of Nrf2 protein in this study is in accordance with research according to Schoeder that the administration of amlodipine doses 4 and $10 \mathrm{mg} / \mathrm{kg}$ in mice 
with acute mountain sickness models are able to activate the $\mathrm{Nrf} 2$ protein through the action of amlodipine on the L-type Calcium Channel on the $\mathrm{N}$ binding site [8].

However, in some groups there was a decrease in the expression of $\mathrm{Nrf} 2$ protein after giving amlodipine at a dose of $5 \mu \mathrm{M}$ indicating the activation of another pathway other than the Nrf2 pathway after amlodipine administration. It is estimated that one of these pathways is the activation of the $\mathrm{NF}-\kappa \mathrm{B}$ protein pathway which is a transcription factor protein for inflammatory processes through the role of intracellular $\mathrm{Ca}^{2+}$ ions. The intracellular $\mathrm{Ca}^{2+}$ ion will cause activation of the calmodulin-calcineurin-IKK complex signaling pathway and calmodulin-CaMKII-IKK complex whose end result of these two signaling pathways in the cell nucleus is an increase in the stimulation of expression of the $\mathrm{NF}-\kappa \mathrm{B}$ protein [11].

Another cause of the insignificant results of this study is that in chronic hyperglycemic conditions there is a decrease in Nrf2 protein expression due to decreased regulation of $\mathrm{Nrf} 2$ protein in the nucleus so that $\mathrm{Nrf} 2$ protein activity remains stable in the cytosol even after amlodipine is given [7]. It is estimated that in this study administration of amlodipine at a dose of $5 \mu \mathrm{M}$ influenced the results of the study which were not significant. This is in accordance with Lee's research on the administration of free radicals $(\mathrm{H} 2 \mathrm{O} 2)$ in cortical neuron cells from mice showing the administration of amlodipine which is neuroprotective to restore viability of cortical neuron cells exposed to free radicals in the dose range of $100 \mathrm{nM}-1 \mu \mathrm{M}$ [12].

\section{B. Relationship of $\mathrm{Ca}^{2+}$ ions with $\mathrm{Nrf2}$ protein}

In this study, $50 \mathrm{mM}$ glucose induction was treated with amlodipine $5 \mu \mathrm{M}$, the result of increased expression of $\mathrm{Nrf} 2$ protein but was not statistically significant compared to without giving amlodipine in SH-SY5Y neuron culture through examination with immunofluorescence methods. The increased expression of the Nrf2 protein in this study is consistent with the theory that an increase in intracellular $\mathrm{Ca}^{2+}$ ions due to chronic hyperglycemic neuron cell conditions will activate the Nrf2 protein via the PRKCA (Protein Kinase C-Alpha) pathway [13]. This insignificant result is predicted that giving amlodipine at a dose of $5 \mu \mathrm{M}$ will activate other pathways in accordance with the research according to Belleazza, namely an increase in intracellular $\mathrm{Ca}^{2+}$ ions will increase activation of the NF- $\kappa \mathrm{B}$ protein and decrease Nrf2 protein expression [14]. Activation of the $\mathrm{NF}-\kappa \mathrm{B}$ protein by $\mathrm{Ca}^{2+}$ ions is through the calmodulin-calcineurin-IKK signaling complex and calmodulin-CaMKII-IKK complex whose end result of these two signaling pathways in the cell nucleus is an increase in the stimulation of the expression of $\mathrm{NF}-\kappa \mathrm{B}$ protein [11].

\section{The Relationship Between Amlodipine $5 \mu \mathrm{M}$ and Without Amlodipine Induced by $50 \mathrm{mM}$ Glucose}

In this study there was a weak but not statistically significant relationship between the $5 \mu \mathrm{M}$ amlodipine group and the group without amlodipine for increased expression of $\mathrm{Nrf} 2$ protein in SH-SY5Y cell cultures induced by $50 \mathrm{mM}$ glucose. An increase in Nrf2 protein expression in $54 \%$ of the treatment group given amlodipine $5 \mu \mathrm{M}$ according to Schoeder's theory is that giving amlodipine reduces influx of $\mathrm{Ca}^{2+}$ ions through amlodipine binding with L-type Calcium Channel on the $\mathrm{N}$ site binding section so that it activates the Nrf2 protein [8]. Whereas a decrease in Nrf2 protein expression in $46 \%$ of the group showed that administration of amlodipine was able to activate other pathways besides Nrf2 protein.

It is estimated that one of these pathways is the activation of the NF- $\kappa$ B protein via the role of intracellular $\mathrm{Ca}^{2+}$ ions so that it will reduce the activation of the $\mathrm{Nfr} 2$ protein pathway even after being given amlodipine [14]. The mechanism of inhibition of the Nrf2 protein by activation of the $\mathrm{NF}-\kappa \mathrm{B}$ pathway is not fully understood. The existence of a weak relationship between the $5 \mu \mathrm{M}$ amlodipine group and the group without amlodipine can also be caused because the administration of $5 \mu \mathrm{M}$ amlodipine has a weak effect that is equal to 0.45 by calculation through the formula d-type effect size.

In this study the number of samples used in giving amlodipine $5 \mu \mathrm{M}$ and without amlodipine were 7 and 6 samples, respectively. Because in this study there are cells that are not included in the inclusion criteria and the number of limited samples that have been prepared for management. The number of samples used in this study were 16 samples. This will affect the results of the statistical test (effect size and alpha value) because the number of samples used in the study has a relationship that is proportional to the strength of the study (effect magnitude and alpha value). The alpha value of the study will also be small [15].

\section{CONCLUSION}

Amlodipine dose of $5 \mu \mathrm{M}$ in SH-SY5Y cell culture induced by chronic hyperglycemia (levels of $50 \mathrm{mM}$ ) has no effect on Nrf2 protein. It does not correspond to the relationship between amlodipine dose of $5 \mu \mathrm{M}$ and without amlodipine to replace the Nrf2 protein in SH-cell culture. SY5Y.

Amlodipine administration can increase Nrf2 protein but it is not statistically significant in estimating the influence of factors such as factors such as transition paths, amlodipine assistance in hyperglycemic conditions, the amount of amlodipine that is too high, and the number of samples used in research is lacking.

\section{ACKNOWLEDGMENT}

This research was carried out with the financial support of BPPM (Agency for Research and Community Service) Faculty of Medicine, Brawijaya University, Malang, Indonesia.

\section{REFERENCES}

1. Baynest, H.W., Classification, pathophysiology, diagnosis and management of diabetes mellitus, Journal of Diabetes \& Metabolism, $2015,06,05$, pp. 541 
2. Mihardja, L., Soetrisno, U., Soegondo, S., Prevalence and clinical profile of diabetes mellitus in productive aged urban Indonesians., Journal of Diabetes Investigation, 2014, 5, 5, pp. 507-512.

3. Roglic, G., WHO Global report on diabetes: A summary, International Journal of Noncommunicable Diseases, 2016, 1, 1, pp. 3

4. Nurlaela S., Kurniawan S.N., Husna M., Electroneuromyography examination of diabetic polyneuropathy patients, Malang Neurology Journal, 2019, 5, pp. 1-4.

5. Zalukhu, M.L., Pinzon, R.T., Adnyana, K.S.G., The profile and determinant factors of quality of life in patients with diabetic neuropathy, Kesmas: National Public Health Journal, 2017, 12, 1, pp. 38-42.

6. Fernyhough, P., Calcutt, N.A., Abnormal calcium homeostasis in peripheral neuropathies, Cell Calcium, 2010, 47, 2, pp. 130-139.

7. Kumar, A., Mittal, R., Nrf2: a potential therapeutic target for diabetic neuropathy, Inflammopharmacology, 2017, 25, 4, pp. 393-402.

8. Lisk, C., McCord, J., Bose, S., Sullivan, T., Loomis, Z., Nozik-Grayck, E., Schroeder, T., Hamilton, K., Irwin, D.C., Nrf2 activation: a potential strategy for the prevention of acute mountain sickness., Free Radical Biology \& Medicine, 2013, 63, pp. 264-73.

9. Shi, H., Liu, K.J., Effects of glucose concentration on redox status in rat primary cortical neurons under hypoxia, Neuroscience Letters, 2006, 410, 1, pp. 57-61.

10. Kanou, K., Sano, M., Kohno, H., A net design for estimating the vertical distribution of larval and juvenile fishes on a tidal mudflat, Fisheries Science, 2004, 70, 4, pp. 713-715.

11. Lilienbaum, A., Israel, A., From Calcium to NF-KB Signaling Pathways in Neurons, Molecular and Cellular Biology, 2003, 23, 8, pp. 2680-2698.

12. Lee, Y.J., Park, H.H., Koh, S.H., Choi, N.Y., Lee, K.Y., Amlodipine besylate and amlodipine camsylate prevent cortical neuronal cell death induced by oxidative stress, Journal of Neurochemistry, 2011, 119, 6, pp. $1262-1270$

13. Kurniawan, S.N., Utomo, D.H., Rudijanto, A., Rahayu, M., Aulanni'am, A., Nuclear Factor Erythroid 2 activation mediated by PRKCA in increasing $\mathrm{Ca}^{2+}$ intracellular in diabetic condition, International Journal Bioautomation, 2018, 22, 2, pp. 159-168.

14. Bellezza, I., Giambanco, I., Minelli, A., Donato, R., Nrf2-Keap1 signaling in oxidative and reductive stress, Biochimica et Biophysica Acta Molecular Cell Research, 2018, 1865, 5, pp. 721-733.

15. Dumičić, K., Žmuk, B., Use of power of analysis in choosing appropriate sample size for quality inspection, Poslovna Izvrsnost Zagreb, 2013, VII, 1, pp. $147-160$.

\section{AUTHORS PROFILE}

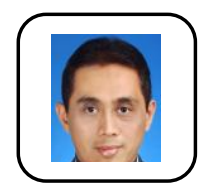

Shahdevi N. K. is $\mathrm{PhD}$ in neurophysiology, Neurology Department, Medical Faculty of Brawijaya University, Malang, Indonesia.

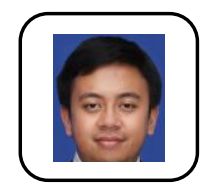

Muhyiddin A. A. A. is student at Medical Faculty of Brawijaya University, Malang, Indonesia.

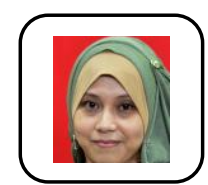

Machlusil H. is PhD candidate at Neurology Department, Medical Faculty of Brawijaya University, Malang, Indonesia. 